\title{
Conflict prevention and resolution in Africa and lessons from the past: The Democratic Republic of Congo up to 2003 with comparisons from Mozambique
}

\author{
By Isaac C. Lamba, Lilongwe / Berlin*
}

I.

In this study in conflict prevention and resolution in Africa it is imperative to isolate the different levels of the conflict for a proper appreciation of the resolution strategies. The dynamics of conflicts in a colonial situation would particularly require this categorisation, based on periodization of events.

In the Democratic Republic of Congo (DRC) as in almost all colonial situations in Africa conflicts start from the typically local level between ethnic groups competing for control of opportunity and resources. This stage can include eventually larger or wider conflagrations of clans, chieftaincies or kingdoms. The second level involves the encounter of foreigners and local political entities, European adventurers or explorers and the chiefs. At this level the focus of the foreigners, usually on trade, operates initially with local cooperation and collaboration which however diminishes with the development of intensified European interests designed to reduce and subjugate the Africans in order to gain full control of the local resources. This stage will entail armed conflict known as primary resistance, in defence of competing economic and political interests and power. This conflict is resolved by survival of the fittest, usually the colonial force. The next level represents sustained local reaction to foreign domination which transcends ethnic dimensions to eventually assume mass nationalist political uprising designed for total replacement of the colonial order with independence.

Conflicts characterizing the post-colonial scene arise from disillusionment often created by poor governance, corruption, diminishing human rights and increasing poverty and hopelessness. This conflict sometimes in the form of civil wars occasionally assumes an ethnic character as was the case in the Biafran war triggered by the Ibo tribe in Nigeria. In the case of the DRC this ethnic dynamic has been complicated by external and extra-territorial intervention to exploit and plunder Congolese natural resources and wealth. This stage can be repetitive and cyclic and engenders enormous political turmoil.

The second largest country in Africa, located in the heart of the continent, the Democratic Republic of Congo (DRC) is endowed with enormous natural resources that include diamonds, cobalt, gold, copper apart from the rich tropical rainy forest for timber. But the

* Lamba, Isaac C., holds BA (Malawi), BEd and MA (Dalhousie) and PhD (Edinburgh) degrees. He has taught at Chancellor College, University of Malawi for over 25 years and is now the Ambassador of Malawi in Germany after serving as Ambassador at the United Nations in New York and Deputy Ambassador to France and UNESCO in Paris. E-mail: lambaic@ yahoo.com. 
DRC's potential for greatness has been negatively impaired by a history of crisis which has up to this time defied conflict resolution efforts and the search for an environment for regime security. The wealth of the Congo has posed as one of the greatest catalysts for international scramble in the recent history of the destabilization of the country.

The history of the Congo has been characterised by violent conflicts from the 1950's through decolonisation in 1960 to the present day government of President Joseph Kabila. The crushing question is whether the Congo crises have always been beyond prevention and resolution. Have the causes of the conflict been properly understood for appropriate resolution strategies to be formulated?

II.

For early prevention to be effective, the multidimensional root causes of conflict need to be identified and addressed. The proximate cause of conflict may be an outbreak of public disorder or a protest over a particular incident, but the root causes may be, for example, socio-economic inequities and inequalities, systematic ethnic discrimination, denial of human rights, disputes over political participation or longstanding grievances over land and other resources. 1

In the apt summary of causes of conflict most of which apply to the DRC, the United Nations Secretary General has mentioned the variations in the degree of conflict manifestations from one society to another depending on the existence of "coping mechanisms ... including well functioning governance and rule of law institutions". 2 In some situations conflict may sometimes be deceptively non-existent and yet covert disagreements have a potential to attain explosion.

This essay acknowledges conflict as a phenomenon characterising every society as long as competition marks people's interaction and relationships. However while conflict may operate covertly as a social function, it is the conflict engendering violence and loss of life which represents the substance of this discussion. The silent form of conflict may not require any outside intervention, but violent conflict invariably poses a threat and challenge that necessitates the involvement of third party mediation in an attempt to restore destabilised peace and security. The third party involvement in conflict resolution may come up in a bilateral form through an organisation or another state, or through multilateral engagement.

While resolution suggests intervention designed to settle the existing conflict, prevention presupposes advance diagnosis of a shifting status quo of peace ingredients. Prevention must therefore operate proactively as a pre-emptive action based on full and close under-

1 "Prevention of Armed Conflict: Report of the Secretary General" (57 $7^{\text {th }}$ Session of the General Assembly, Agenda 10, A/55/985 - S/2001/574, New York, 7 June, 2001), p.7. Hereinafter "Pre2 vention of conflict: Report of the Secretary-General".

Ibid p.6. 
standing of the circumstances whose symptoms of destabilisation become clear and invite the appropriate intervention. The primary stage of prevention therefore provides a more complex scenario for interpretation and diagnosis while the secondary stage benefits from past experience. In its strict sense prevention of armed conflict presents an alternative less costly in terms of money and human resources than resolution. The Carnegie Commission's suggested expenditure of $\$ 200$ billion that have been spent on seven major conflicts and interventions in the 1990's would have cost, as indicated in the UN Secretary General's Report(2001), only about $\$ 70$ billion through preventive action with very few or no people dead.

In a study of 1991 Copson portrayed conflicts in Africa as "deeply rooted in African states and African societies" and cited, as crucial causes of conflict, fundamental social cleavages within African states along ethnic and regional lines, reinforced by religious and income difference .... Africa's poverty which deprives African societies of the means of easing tensions is another. The tendency of many governments to rule through arbitrary and repressive means has provoked violent conflict and armed resistance in many instances. ${ }^{3}$

Copson's analysis of causes of conflict indicated above implicity introduces the complexities of conflict prevention as echoed in the Kofi Annan report of 2001 to the General Assembly. However, any effective approach to address conflict prevention must take cognisance of the two categories of strategies presented by the Carnegie Commission on Preventing Deadly Conflict. There is structural prevention which, on diagnosing, introduces measures to create a blockage of any potential skirmish, and as operational prevention, to address an immediate crisis. Capacity for non-violent primary conflict resolutions should always form the ideal. If the suggestion holds any truth that democratic societies have mechanisms that keep conflicts to a minimum through some equitable distribution of opportunity, then the converse explains the sad situation in developing countries most of which are still in the process of democratisation, a situation which calls for deeper understanding. The United Nations suggested support for structural prevention as a prerequisite for sustainable peace and development touches on root causes of conflict which if carefully managed could indeed ensure peace, security and development. In this discussion the questions to address should include the existence of a prolonged conflict, both unarmed and armed, in the DRC and whether any conflict prevention mechanisms proved effective elsewhere would have worked in this huge, multi-ethnic and multi-linguistic Central African country.

Capson, Raymond W., "Peace in Africa? The influence of Regional and International Change", in: Francisco M. Deng and I. William Zartman (eds), Conflict Resolution in Africa, Washington DC 1991, cited in: Mwelwa C. Musambachime, "Prospects and constraints to Peacekeeping and Peace-building in the Democratic Republic of Congo", (typescript privately held), p.1. Hereinafter Musambachime, "Prospects and Constraints to Peacekeeping..." 
III.

The profile of conflict in the Democratic Republic of the Congo (DRC) has recorded no genuine peace in the country over close to half a century. To most people on the international scene conflict in the DRC has become more popularised by the first war or armed conflict launched in 1998. But this internationalised civil war only represents the epitomy and climax of conflicts in the history of that country even predating the granting of independence by Belgium, the colonial power, on 20 June 1960. The antecedents to the war characterising the pre-1997 period therefore shed important light to our understanding of the intricate causes and exacerbation of the conflict from 1997. It is no exaggeration to suggest that in terms of magnitude this war ranks among the deadliest recorded in Africa especially in the post-Cold War period, causing the death of an estimated 2 million Congolese. Apart from the enormous social and economic disruption, foreign armies took advantage to occupy huge portions of the Congo while other armies came on invitation to assist in defending Kabila's government. The DRC has suffered untold economic exploitation at the hands of these foreigners who have taken advantage of the armed conflict to promote their own illegal economic interests and agenda. Looking at the Congo in a microcosm, Clark's observation gathers poignancy. "As ordinary observers of human frailties, cruelties, and heroism we cannot help but be fascinated by Congo and its travails; as moral beings, we cannot help but be gravely concerned with the unspeakable human suffering that has resulted from the recent war, as well as Congo's other post-colonial traumas."4

\section{Post-Colonial Crisis}

If peace is considered elusive in Africa the explanation is partly demonstrated by its profile which has recorded more than thirty wars on the continent from 1970. The DRC is included in this sad historical commentary. Apart from people's suffering and destitution caused by wars, more than 2 million people lost their lives in Africa between 1988 and 1998 alone, with 10 million people internally displaced or forced into migration.

Like most African countries the DRC's socio-economic and political structure created a blueprint for possible violent conflict. Nzongola-Ntalija's exposé of the situation presents a lucid description of the socio-economic basis of the pre-independence problem in the DRC. ${ }^{5}$ The post-colonial DRC demonstrated the failure of a local political leader to effectively and efficiently run a popularly constituted regime and deliver the promised benefits. This situation can create either a national uprising or violent hostilities based on ethnic loyalties. This dangerous stage has led to the collapse or disintegration of several states including for example, Somalia and indeed the DRC itself. The destabilisation is exacer-

Clark, John F. (ed), The African Stakes of the Congo War (Introduction), New York 2002, p.1. Hereinafter Clark, African Stakes.

5

Nzongola-Ntalaja, Georges, The Congo from Leopold to Kabila: A People's History, London 2002, ed 2, pp 61-93. Hereinafter Nzongola-Ntalaja, Congo. 
bated by corrupt leadership which is extremely bent on self-aggrandizement and DRC's Mobutu Sese Seko represents a case in point. The disintegration of the DRC (Zaire) state was marked by the rise of several "group" leaders determined to gain control through violent force to fill the vacuum of the political power centre. The ensuing violent conflict led to ethnic realignments in the formation of military fronts. Prevention of ethnically based wars presents a highly complex challenge because of the occasional narrowness of the objectives that spur groups into armed conflict. Furthermore the permanence of peace following a civil war is often doubtful since the risk of a further war is said to be as high as 40 percent. $^{6}$ But this is a situation that benefits from third party monitoring and peace building which has been subjected to vigorous test in the DRC.

Was the crisis which ushered in Mobutu's downfall inevitable? Could it have been prevented? To what extent was the arrival of Kabila a solution to the crisis? What factors have sustained the DRC conflict up to the 2003 peace agreement signed by all parties? These are important questions in the study of conflict prevention and resolution in the Congo.

In the political history of the Congo, independence on 30 June, 1960 opened the door to the country's worst crisis when internal violence fuelled by external intervention during the Cold War era led to the deposition and assassination of the first Congolese Prime Minister and head of government, Patrice Lumumba, considered by westerners to have been communist-oriented and therefore a threat to the western alliance. Joseph Kasavubu, the leader of the Aliance des Bakongo (Abako) became the ceremonial president and generally considered pro-western.

The period immediately after June 1960 introduced the most challenging epoch in the history of Congolese crises. The United Nations (ONUC) was brought in to resolve the ensuing war threat but registered dismal performance which only contributed to the deterioration of political confusion. There had been clear signs of this post-colonial crisis in the Congo but prevention did not seem possible and resolution through external intervention formed the most protracted chapter of failures in the story of DRC's political independence.

The ideological proliferation in the pre-independence period created cleavages in Congolese society based not only on economic alliances but also on potential external military support in the jockeying and manipulation for political control to complicate the political environment. Polarity among the Congolese leaders was characterised by the enormous hunger for power; even the seemingly national radical party of Patrice Lumumba, the Mouvement National Congolais (MNC) split. Power-sharing did not feature as an ideal for preventing the fracas of 1960 . Not much interest existed to prevent the crisis at individual, national or even international levels. While individual leaders were too engrossed with personal ambition, no third party intervention seemed forthcoming to nip the crisis in the bud. Belgium, as the departing colonial power was conscious of the inevitability of her 
departure from Africa but did not seem anxious to leave behind a stable independent Congo. America, anxious to dislodge Soviet influence in Africa supported usurpers and moderates ${ }^{7}$ who would ensure a strategic pro-western stance even at the expense of violent internal conflict through the decline of institutional capacity. Such decline would only serve as a potent recipé for violent struggle of grave national consequences in the disintegration of the Congolese state.

From independence day in 1960, events moved fast in the Congo in the wrong direction. The conflict with root causes perceived for a long time now degenerated into violence which claimed many lives ending with a military coup by Joseph Mobutu in 1965. In an effort to avert direct Soviet-American confrontation in the Congo the Security Council of the United Nations agreed to deploy about 20,000 troops with a huge contingent of civilian personnel. Immediate important events giving rise to the ensuing general political chaos which led to state failure were few. Belgians allegedly incited a nationwide army mutiny and secession of the huge mineral rich Katanga province and South Kasai as a showdown to the pro-East Lumbumba. Belgians intervened militarily on 10 July, 1960; the secession was announced the next day. A huge white mercenary group took advantage of the civil conflict. Lumumba's appeal for a UN peacekeeping force represented a desperate act since there was no peace to keep. Disagreement between Lumumba and the UN Secretary General Dag Hammarskjold in the interpretation of the peacekeeping mission within the context of the Cold War and western neo-colonial interests resulted in the assassination of Lumumba through what has been described as a US and Belgian-led initiative in order to address strategic dilemmas. The "Congo Crisis" 1960-65, a crisis of Belgian decolonisation, represents a struggle for a second independence by Africans in pursuit of frustrated political expectations.

Military violence in the Congo was wrongly seen as potentially capable of restoring political stability. The conditions of conflict prevention in 1960 in the Congo did not seem to exist because the various root causes including economic exploitation, ethnic discrimination, deprivation of opportunity all of which diminish the capacity of structural prevention were not completely addressed. Preventive diplomacy did not feature as a possible consideration. The response of the UN through its peacekeeping force represented a tacit admission of the failure of prevention of the violent conflict. The second occasion for UN intervention in the Congo came in the late 1990's with the transition from Mobutu to Kabila.

The UN peacekeeping operations in the Congo in 1960 were considered irrelevant and only promoting an already explosive situation. Peacekeeping is impossible without peace on the ground. The Congo could not claim even the semblance of fragile peace because the long term conflict had attained maturity characterised by devastating violence. Peacekeep- 
ing follows the diplomatic conclusion of violent conflict to assist in the monitoring of the peacebuilding process. Peacebuilding, a delicate strategic engagement with the parties in conflict, precedes peacekeeping which is a technical stage in conflict resolution. Lessons from the identified causes of a previous violent conflict form an important body of knowledge useful in preventive diplomacy to forestall subsequent potential violence. In 1960 the crisis in the Congo was exploding and the external or international intervention required negotiations and bargaining to stop the war before a United Nations peacekeeping force. In fact the UN objective should have been peace negotiations first, leading to acceptable constitutional arrangements owned by the people. Peacekeeping serves a purpose different from conflict prevention.

The peacekeeping role, just like peace making and conflict prevention and indeed resolution calls for a neutral player such as the United Nations. However, from its establishment in 1945 very rarely has the UN's involvement in conflict situations yielded for the organisation such dishonour as in the DRC. Its neutrality was not guaranteed and visible. ONUC's terms of reference were condemned by most Africans who saw the performance of the peacekeeping force as identical with a fighting military force. The UN action did not constitute a pre-emptive move. By the time of the UN peacekeeping mission's departure on 30 June 1964 with the nomination of Moise Tshombe as Prime Minister of the Congo the following month, the country's political instability continued unabated and the seeds of a more volatile potential volcano could not be totally ignored.

IV.

The military takeover of power by Col. Joseph Mobutu in 1965 enjoyed western support as the political answer for a destabilised Congo. But the weak base of this "Second Republic" was not addressed to rectify the fundamental problems which played into the hands of Mobutu in his design of a dictatorship up to 1997 when he was militarily deposed. An examination of the underlying lingering difficulties and dilemmas is crucial to understand the performance of conflict prevention and resolution in what 1997 came to be known as the Democratic Republic of Congo (DRC).

At the departure of ONUC in 1964 no comprehensive official inventory had been taken of the root and immediate origins of the armed crisis of the Congo which in any case had not been totally eradicated to prevent any violent recurrence. There was not what the former UN Secretary General, Kofi Annan has called a "coherent peace-building strategy, encompassing political, developmental, humanitarian and human rights programmes"8 to counter the initial military clashes. Socio-economic inequalities precipitated by ruthless western economic exploitation of the Congolese natural resources continued in evidence while 
increasing ethnic polarization marred hopes for the emergence of smooth national democratic politics.

If conflict prevention can be described as homegrown through collective local and national dialogue, the international involvement in the Congo crisis destroyed the prospects for that prevention and jeopardised the achievement of the desired sustainable peace to serve as a prerequisite for holistic development. The UN action of peacekeeping intervention represented reaction instead of the desired initial prevention. Admittedly the UN has over the years redefined its intervention in terms of prevention and peace-building. The functions of the United Nations are now "principally to assist national governments and their local counterparts in finding solutions to their problems by offering support for the development of national and regional capacities for early warning, conflict prevention and long-term peace-building". ${ }^{9}$ The agenda of the UN in the Congo in 1960 and beyond displayed a much narrower thrust. Preventive deployment of the military troops and preventive disarmament constitute a sequel to cessation of violence to serve as prerequisites for peacebuilding characterised by, among other things, confidence-building measures to reduce suspicion. The reality of conflict resolution is a function of time. As Collier has suggested, "immediately after the end of the hostilities there is 40 percent chance of further conflict". 10 The "Congo Crisis" was to continue in different endemic strands as long as the true meaning of national independence in 1960 eluded the over 30 million disillusioned people in 200 ethnic groups. The long political maneuverings, local and international, after Lumumba and leading to the Mobutu takeover in 1965, a period dominated by the "new white" or "moderates", would be too detailed for purposes of this discussion which should now focus on Mobutu's presidency and demise and the dawn of the Kabila era in 1997 up to the signing of the Pretoria Peace Accord, 2003.

\section{The Mobutu Era}

Joseph Desiré Mobutu stood out as one of the most notable and notorious African military dictators after rising to power in a military coup of 24 November, 1965. Mobutu took advantage of his commanding military position to launch a decisive force to end the civilian political impasse following Lumumba's assassination. Mobutu's ascendancy and long dictatorship, which in its effective monolithic form came to an end in 1990, owed its sustenance to external sponsorship and support from the United States and its allies. The continuing political instability in the Congo was inconsequential to Mobutu's design for military rule. This was the biggest blunder which alienated any local legitimacy to his rule. Westerners were more interested in the economic resources of the Congo which in fact only promoted corruption and wealth for the leadership without proper and wider government participation. The absence of democracy and good government in the Congo raised no real 
concern to westerners to whom geopolitical interests that would create in the DRC a bulwark against Soviet influence during the Cold War formed a major preoccupation. Weak leaders such as President Joseph Kasavubu held no promising prospects to protect western interests. An attempt in 1964 at parliamentary 'democratic' national elections turned into a total fiasco. Chaos and factional contests continued which could only be handled decisively by a strong man, General Mobutu through military rule.

A coup entails no prior negotiations aimed at prevention before it takes place. Resolution with no regard for ordinary people subsequently follows but under conditions which never existed in Mobutu's Congo. The coup, justified by Mobutu and his henchmen as the only method to settle the political turbulence in the Congo, gave no regard to the need for popular legitimacy. Any resistance to such a regime was ruthlessly eliminated by force. Interestingly many people exhausted with civil strife welcomed the coup as likely to bring peace and stability. The coup seemed to bring the desired seal to the new political order in the hands of Mobutu and his small ruling oligarchy. The real political crisis was considered by some people to be over, but only deceptively. In effect problems of the Congo could not be sorted out militarily; the political turmoil was only taking on a new resilient texture. The state's fracture, disintegration and collapse could not be prevented as subsequent events during the phase of an illusory peace showed.

Among the various weaknesses of the Mobutu phase especially up to 1990 were not only his fierce dictatorship but also corruption serviced by his allegiance to external forces that brought Mobutu to power as a 'strong' man. The ingredients of continued crisis still remained, albeit in subdued form. Governance without the requisite popular democratic legitimation is impossible and the Congolese society remained politically, socially and economically divided with no semblance of equality of opportunity and security of life which constituted the blueprint for the potential of violence.

The recognition of human equality lies at the centre of peaceful co-existence that characterises a democratic culture. The implied equality suggests individual basic personal liberties which are reflected in entitlement to mutual respect and justice in the operation of "freedom of conscience, thought and expression, as well as freedom from coercion ... Human equality does not imply that people necessarily have the same status, privileges, power, needs or wealth. It does imply that such differences should not be the consequence of one's violation of the other's entitlements."11 If the absence of these peace indicators suggests that fertile ground for conflict, then Mobutu's Congo remained in a state of continuing crisis.

In addressing political conflict two important and critical steps, as implicitly mentioned earlier, include diagnosis of the pathological political state, and mediation. In a military dictatorship edicts or decrees are considered almost infallible. Any popular perceptions of problems cannot be easily communicated for possible diplomatic intervention, negotiation and redress because while the act itself would be dubbed rebellion, the intervenor would be 
charged with treason for attempting to disturb "existing" peace. The punitive drastic consequences would naturally preclude any freedom of speech. Even if the destabilised situation is considered by many, according to I. William Zartman, as ripe ${ }^{12}$ a dictatorship's selfish ambitions will pay no attention to any warning and peace intervention. Any problem of conflict perceived only by one side leaves no room for negotiations and the concept of ripeness becomes irrelevant and dysfunctional to the dictatorship. Values and norms hold no important place in a dictatorship except what props up and promotes the interests of the strong ruling minority.

When Mobutu took power no effort was spared to indulge in personal economic opportunism through economic links with several European economies as well as encourage South African capitalist presence and operations in the Congo. Mobutu then nationalized the giant Union Minière de Haût Katanga (UMHK) for convenient exploitation of its operations to his advantage. Mobutu placed himself in a maze of international competition and conflict in the management of Congo's economy in which he considered all natural resources as his own. Localisation and the concept of 'authenticity' led to enormous corruption and wasteful expenditure not shared by the average Congolese majority who still lived in abject poverty. The environment had the potent ingredients for open conflict, eventually. Apart from personal economic domination Mobutu's grip of the military and external sources of diplomatic support marked the zenith of his dictatorial rule which reached its twilight by 1990. As Nzongola-Ntalaja observes, "between April 1990 and February 1991 the Mobutu regime lost the ability to use its instruments of power for purposes of intimidating the people and keeping them down." ${ }^{\text {13 }}$ But the strategy of intimidation always outlives its time.

The year 1990 marks an important watershed in human history. The fall of the Soviet Union in 1989 led to the reordering and rearrangement of alliances and ideologies. The global impact of the collapse and demise of the Cold War and the Iron Curtain, which called for a democratic culture, swept throughout Africa where single party totalitarian regimes, a number of them military, could no longer succeed in suppressing popular aspirations. Mobutu's Congo regime was not spared as people's fear of the dictator disappeared. The last vestiges of the dictatorial state disintegrated rapidly. The western world now considered the Congo irrelevant to their geopolitical strategy of blocking the interests of the now defunct Soviet Union.

Mobutu's loss of moral authority and the repressive apparatus was exacerbated by discontent in the poorly paid armed forces which were now engaging in acts of looting and internal fighting. Mobutu never served as an honest surety of his people. From 1990 the political ideology of democracy rapidly subduing communism resounded in Africa including the Congo when the call for multi-party democracy gained new vigour. Congo politics 
entered a new phase when the Congolese stood up in open defiance and resistance to Mobutu's excesses. People attempted to react against Mobutu before 1990 but the repression using the strong state military and security apparatus always ensured Mobutu's survival. It was now time for the opposition alliance to re-establish the virtues of legitimate leadership through sustained defiance.

Conflict prevention and resolution becomes possible where the opposing parties are willing to negotiate the means to their shared political ideals embedded in a democratic culture. Until 1990/91 when Mobutu's dictatorial grip on the Congolese had shown decisive cracks, any suggestion of diplomatic intervention and negotiation in the political crisis was unacceptable to the dictator who denied the existence of any turmoil in his country. Rejecting any possibility of sharing wealth and power with the people, Mobutu refused to recognise the problem and possible solutions until the situation in 1990 forced him to turn around in shame and humiliation. The recognition of a problem constitutes a most critical prerequisite in any peace negotiation. Peace cannot be externally generated. Effective conflict prevention or resolution rests on the support of "the people and groups directly affected by the conflict" ${ }^{\prime 14}$ As long as the ruthlessness of the military formed an instrument to enforce coercion, any peaceful discussion, negotiation and bargaining was not possible in the pre-1990 Congo. Under a military dictatorship, since negotiation and bargaining do not feature as necessary, the dictator's word serves as law eliciting everyone's compliance which in no way suggests total acquiescence as much as a desire to survive. Where an opportunity for dissent exists it can reward the reticence and resilience of conflict. Sometimes violent conflict will be averted where a ruler attempts some amelioration of difficult conditions such as poverty, corruption, disease, or deprivation of resources. This was not the case with Mobutu.

In sum, various destabilising agents in the DRC included confused regime change from colonialism to independence, the rise of a dictatorship, poverty, competition for scarce resources and frustrated expectations with no legal recourse partly because of weakened institutions of government. The Congo has shown the threat to peace created by external political, economic and military interests. Even the United Nations failed to come up with a potent strategy for conflict prevention and resolution.

\section{The Mozambique Comparison}

Up to 1991 an interesting comparison with the DRC comes from Mozambique. While conflict risk factors will vary between countries reflecting the differences of individual societies, a few similarities between the Congo and Mozambique exist. Portugal gave independence without ceremony to all its African colonies including Mozambique in 1975 after protracted and inconclusive colonial wars in Africa at the peak of the Cold War. Almost all 
ex-Portuguese colonies strengthened their links with the Soviet Union which had provided both moral, ideological and material support to freedom fighters especially prior to 1975 . The Congo on the other hand stood as a pro-western pillar against Soviet influence. The struggle between capitalism and communism or socialism in these countries stood out as one of the important indices of conflict which in Mozambique continued until the signing of the 1992 General Peace Agreement in Rome. The Portuguese passed on rule to any strong political party in the colonies; in Angola it was the MPLA under a socialist, Dr. Augustino Neto and in Mozambique the FRELIMO party under Samora Machel, another avowed socialist.

Africans in Mozambique staged resistance from the 1960's against the centuries-old cruel Portuguese colonial system. Just as in the DRC the classic root causes of African discontent included "endemic poverty, inequalities in access to resources, insecurity, violation of human rights perpetrated by harsh and violent approach to governance, exclusion or persecution of sectoral groups", ${ }^{15}$ and absence of capacity and political legitimacy of a government whose major interest was in the exploitation of Africa and its resources.

In 1960 the conflict in the Congo between nationalists and the Belgian colonial power would compare with that in Mozambique up to 1975. In both countries external forces played a huge destabilizing role during the Cold War. For Mozambique, South Africa and the then Rhodesia strove to dislodge the FRELIMO socialist government and leadership in favour of a pliant pro-western regime. In the end the military incursion by the two white regimes supported by America and other western countries led to their sponsorship of Alfonso Dhlakama's RENAMO guerrilla movement against the governing FRELIMO. Peace, unknown to Mozambique from 1961 to 1992, finally came with the signing of the Agreement. From independence in 1975 Mozambique played the role of a war arena against other nations, some of whom fought by proxy. While the neighbours Zambia joined by Zimbabwe from 1980 fought in varying capacities on the Mozambique government side, South Africa and Rhodesia propped up the military ranks of RENAMO, initially led by Matsangaissa who on his death in 1979 was succeeded by Alfonso Dlakama. ${ }^{16}$

The period of violent civil war in Mozambique from 1975 to 1992 finds a parallel in the DRC especially from 1965 to 1997, when single party politics in each of these countries gave way to the reality of a multi-party dispensation. In Mozambique conflict resolution matured with the General Peace Agreement of 1992 and Mozambicans have since then pursued a path of peace and development captioned by a democratic culture. The DRC, on the other hand, has gone through the painful process of negotiations internally and with external involvement yielding no promise of success; the Pretoria Peace Agreement signed

International Peace Academy(IPA), Sharing Best Practices on Conflict Prevention, New York 2002, p. 2. Hereinafter IPA, "Best Practices. Ending Mozambique's War: The role of Mediation and Good Offices, Washington DC 1994, pp. 3-23. Hereinafter Hume, Mozambique's War. 
April 2003 by all Congolese belligerents, had not yet succeeded to stop completely the sporadic fighting but the resolve for successful implementation of the Agreement signified prospects for real peace which would demand strong leadership and political will.

As demonstrated earlier the DRC and Mozambique shared similar causes of their respective crises. These issues included poverty, economic disparities more pronounced in the DRC than in Mozambique, corruption, absence of multi-party democracy, human rights abuses, insecurity and international political and economic adventurism. As it happened the impending crises which aimed at regime change simply needed time and could not be prevented. However, the operational dynamics of peace negotiations between the two countries exhibited dissimilarities.

While the Congo crisis had attracted religious and United Nations intervention from the late 1990's after Mobutu, the Peace Agreement for Mozambique was negotiated through the external intervention of NGO's and indeed religious groups. It is not easy to argue on the basis of the intensity of the conflict to explain the undoubted success of conflict resolution and peacebuilding in Mozambique in comparison with the slow progress in the DRC. Both countries experienced the worst forms of genocide; millions of lives were lost while millions of people were internally and externally displaced. From the mid-1970s Malawi alone, which shares a border with Mozambique played host to about 1.3 million Mozambican refugees who returned to their country only after the peace agreement of 1992 which ended the civil war. Could the devastating wars have been averted through intensified internal negotiation effort? To competently address this question a cursory examination of internal peace efforts in the two countries is important.

\section{Internal Peace Efforts in the DRC}

By 1990, with the demise of the Soviet Union and the subsequent geopolitical external realignments in Africa, Mobutu's iron rule was no longer sustainable. A new political dispensation of inclusiveness in government had become inevitable. Mobutu's autocracy and repression, corruption and human rights abuses had to countenance the forces of democratic accountability and transparency to check the "rape of the Congo". 17 It is important to note that even at the peak of Mobutu's dictatorship a Congolese voice of protest and resistance existed, although generally in subdued form. Civil society and students took the lead. For example a demonstration took place in January 1968 by the UGEC (Union general d'etudiant conglais) at Lovanium University against the US Vice President's (Hubert Humphrey) visit to lay a wreath at the Lumumba monument. The protest showed the existence of internal opposition which collaborated with externally based opposition groups.

Mobutu resisted reform even as suggested by America as early as 1975 . In 1980 a 52page letter from 13 Members of Parliament to Mobutu demanding reform led the Group of 
13 into jail. Etienne Tshisekedi wa Mulumba emerged as the leader of the opposition forces which always encountered Mobutu's wrath. Until 1990 when Mobutu finally succumbed to the philosophy of popular consultations on the country's destiny, opportunities to avert the violent resistance of the late 1990's had been squandered and assassinated. Steeped in his dictatorial greed and grip Mobutu locked up political will for meaningful negotiation and change that would have avoided bloodshed of the mid-1990's. Tshisekedi's "Union pour la democratie et le progress social" formed in 1988, though illegal but popular with the masses, provided an important medium for any peace negotiation.

Mobutu's disillusionment in 1990 seemed a night too late for peaceful creation of democratic institutions closer to the popular masses from whom he was politically detached. However, beleaguered, Mobutu's plight increased when his public announcement on 24 April, 1990 to discontinue the single party system led his former allies to abandon him and form their own political associations which later created an alliance to oppose him. Of significance in the new democratic process was the convening on 7 August, 1991 of the landmark Sovereign National Conference (SNC or CNS) chaired by the Catholic Archbishop of Kisangani, Monsignor Monsengwo.

If the national conference failed to bring about a multi-party transitional institutional framework both the participants and the President shared the blame. The latter took advantage of the delegates' disunity and lack of a shared vision. Mobutu's appointment of a Prime Minister from the opposition meant little and proved temporary. The three important players in the search for a political solution were Mobutu, Tshisekedi and Monsignor Monsengwo, with some American involvement. Mobutu's wriggling led to the dismantling on 1 December, 1992 of the negotiating process and its provisional constitution, reverting to the status quo of political uncertainty. The major achievement of the CNS was its impact in raising the level of political consciousness among the Congolese who were now more determined to challenge Mobutu and his government. The ideals of the democracy movement had been strengthened. The period 1992 - 1996 can be described as that of subdued democratic political activity despite the aborted transitional constitutional arrangements. The Congo had turned into a failed state under Mobutu by the time of Laurent Kabila's takeover in 1997.

The failure and collapse of a state can be attributed to a number of factors which in fact apply to the DRC. These factors include loss of legitimacy of the leadership, through inability to efficiently serve the interests of the people; disregard of norms and human rights. ${ }^{18}$ Laurent Kabila's toppling of Mobutu in 1997 was welcomed specifically to correct Mobutu's mistakes and revive a dilapidating potentially democratic state. Kabila's assassination on 16 January, 2001 represented a testimony of people's continuing political anxieties and restiveness. Could the international community have prevented further deterioration of events in the Congo from Mobutu's departure in 1997? Before answering this ques- 
tion Mozambique provides relevant comparisons with the Congo up to 1996 except that Mozambique prevented a violent regime change, an achievement in itself in peaceful conflict resolution.

The major difference between the $\mathrm{DRC}^{19}$ and Mozambique in the performance of mediation and conflict lay in the quality, aspirations and commitment of the leadership underlined by political will. These countries had experienced a long excruciating conflict with bitter humanitarian consequences and the question of human rights violations which featured prominently in both; but Mozambique generally operated under a more conscientious leadership characterised by tolerance and patience. In this comparison the dynamics must be examined which led to Mozambique's General Peace Agreement (Rome Agreement) of 4 October, 1992 ending the civil war and Congo's Lusaka Agreement between President Laurent Kabila and his internal and external political opponents brokered by the Southern African Development Community (SADC) leaders whose implementation had faced huge problems.

Although peace accords commonly start their life with turbulent experiences, as Crocker $e t a l^{20}$ have indicated, peace agreements take varying periods of time to settle. The Mozambique Peace Agreement took a comparatively short transitional period after signing. The DRC Lusaka Agreement failed to deliver the expected peace and political instability had continued until the time when the Pretoria Agreement (2003) came and seemed to offer signs of hope for peace. The explanation to this difference lies in political leadership and state structure. While the Mozambique Presidency continued strongly to uphold the state structure during the civil war, the Congo situation was marked by the absence of strong and effective legitimate central leadership in a virtually collapsed state. Another factor was the heavy military involvement of so many external forces in the DRC, carving out economic advantages with impunity in the name of peace in a country too weak to hold itself out. "In 2002 approximately half of the DRC was under the fragile control of rebel movements kept alive by .. direct military assistance from their respective sponsors." ${ }^{21}$ The proliferation of rebel groups complicated the peace process in the DRC, unlike in Mozambique where only two major parties, FRELIMO and RENAMO, the local adversaries, constituted the negotiating sides, a factor which made sustainable reconciliation of the warring parties easier than in the DRC situation.

Details on the Congo see Lemarchand, René, The Democratic Republic of the Congo: From Failure to Political Reconstruction, in: Robert I.Rotberg (ed), State Failure and State Weakness in a Time of Terror, Cambridge, Mass 2003, Ch. 3. Hereinafter Rotberg, State Failure.

20

See the title of their book, Turbulent Peace; op cit.

21

Rotberg (ed), (above Fn. 19), p.30. 
VI.

The war in Mozambique, with an ideological basis, raged from the late 1970's with RENAMO tactics designed to destroy and disrupt Mozambique's social and economic infrastructure to bring down President Joachim Alberto Chissano's FRELIMO socialist government. But initial peace negotiations had to involve apartheid South Africa, the military sponsors of Renamo. Peace talks of 1984 failed for enormous lack of mutual trust between the beligerents, which represents a critical ingredient in peacemaking. Meanwhile the war devastation was escalating.

The first major important move by the Chissano government was the consideration to abandon socialism and adopt political and economic liberalisation and pluralism. A multiparty democratic political system with other reforms featured in a new constitution by 1990. These moves turned FRELIMO's tide to win western support, thereby politically isolating RENAMO. Economically and financially weak the government opted for realistic options which now excluded a military solution to the war. The huge humanitarian catastrophe in Mozambique could no longer be ignored or glossed over, with about $1 \frac{1}{2}$ million refugees being hosted by Malawi alone.

Just as in the DRC, Mozambique's peace process benefited from both internal and external mediation, using a variety of modalities considering that each conflict bears characteristics unique to $\mathrm{it}^{22}$ based on the causes, resources and the existing socio-political environment.

The success of peace negotiations also depends on the neutrality and background of the negotiation facilitators including their known human interests. Furthermore mediation of intra-state conflict (civil war) presents dynamics sometimes quite different from those related to inter-state violent disputes. Failure or success of negotiations will often depend on the form of inducements for the disputants. The timing of negotiations by third parties serves a crucial role; where armed conflict is anticipated, proper timing can sometimes avert its eruption. Third parties will use diverse instruments which may include "contingent offers of recognition, consultations and advice, and provisions for security - so as to address the various aspects of a dispute". ${ }^{23}$ While global and regional players can subvert a peace process by supporting one or the other of the disputing sides, the importance of moderation and patience from the leaders in the conflict cannot be overemphasized. A leader of the nation at war needs to put national peace ahead of personal interests to gain the opponent's confidence and trust within an operational state apparatus. The peace dialogue can start with interlocutors but direct talks are necessary. Both the civil society as

Wallersteen, Peter, Understanding Conflict Resolution: War, Peace and the Good System, London 2002, p.17. Hereinafter Wallersteen, Understanding Conflict Resolution.

23

Lund, Michael S., Preventing Violent Conflicts: Strategy for Preventive Diplomacy, United States Institute of Peace, Washington 1996, p.86. Hereinafter Lund, Preventing Violent Conflicts. 
well as religious groups can also initiate and influence a peace process and Mozambique furnishes a relevant example of this second track diplomacy.

The first problem in the Mozambique peace process was to establish a basis for negotiation which would move from the government description of RENAMO as a 'bandit' terrorist organisation, even if operational realities supported and justified the terminology. The military impasse, humanitarian considerations and need for development intensified government urge for peace negotiations in the late 1980's. This took the President's realistic perception and readiness to humble himself. RENAMO, weary and organisationally weak with dwindling financial and material support also considered a negotiated settlement as the only realistic option. The timing seemed opportune as the collapse of Soviet communism reduced interest among RENAMO's supporters in the geopolitical game in Africa.

The significance of a venue and facilitator for peace talks cannot be underrated. While foreign governments, especially in Southern Africa and Kenya demonstrated an active interest to end the war, indirect contacts between the government and RENAMO won the support and efforts of Italy, Britain, Portugal and the United States and indeed the United Nations. The role of the Catholic Church through its NGO, the Community of San' Egidio, proved extremely delicate but decisive as a facilitator with strong support from the Vatican and the Italian government. Vatican diplomacy was given a chance in a hall in Rome which combined Byzantine architectural expression with an ecclesiastical décor. Considering that over 90 percent of Mozambican Christians are Catholic the psychological impact of the venue was not unanticipated. The choice of venue is therefore crucial to peace negotiations. The first direct meeting in Rome between RENAMO and the government on 8 July, 1990 opened with a former papal call to the Vatican Council "to seek more that which unites than that which divides", 24 in the spirit of compromise. The General Peace Agreement signed on 4 October, 1992 in Rome was the result of patient and careful steering by the mediators whose role involves suggesting changes in the modus operandi depending on their perception of the progress of events because facilitation does not stop at transmission of messages and points of view but also analysing expressed views, manoeuvering and suggesting useful improvements. In the end it is compromise between fighting parties which builds meaningful reconciliation and multiparty democracy.

In summary, the success of the Mozambique peace negotiation depended not only on the readiness of the leadership to give and take and, with courage and resolve, to accept to shift ground even in changing the ideology of the government to accommodate political and economic pluralism, but also the political will to implement the General Peace Agreement. The quality of mediation at an opportune time constitutes a critical variable which however must benefit from experience and the responsibility to make good judgement on both practical logistical organisational matters as well as the central and useful groups to participate 
in negotiations. The external parties can exert and ensure not only international credibility and legitimacy of the outcome but also implementational support for the peace agreement.

In Mozambique, American and Europeans actively influenced South Africa's cessation of its destabilization policy towards Mozambique. The United Nations was entrusted with the task of participating in monitoring the General Peace Agreement and providing peacekeeping and assistance to electoral operations through the United Nations Operation in Mozambique (ONUMOZ). The success achieved in ONUMOZ's delivery of its stipulated functions demanded local and international support which led to the celebration of ten years of peace in 2002. The DRC, despite protracted peace negotiations at various stages from 1990, continued to suffer and exist in a state of conflict until the Pretoria Agreement of 2003. It is important to examine the Mozambique peace checklist in comparison with that of the DRC, of course conscious of salient differences that assist to identify the stumbling blocks.

One of the important distinctions between the DRC and Mozambique is that the former, largely a failed state, has experienced leadership problems in terms of continuity, ideology and commitment. Proliferation of opposition groups in the DRC simply complicated prospects for peace. While Mobutu, the recalcitrant dictator put personal interests ahead of a national agenda, his successor Laurent Kabila, although socialist in ideological orientation, fell victim to Mobutu's trap of pursuing personal financial aggrandisement complicated by international economic pursuits bent on exploiting the DRC's natural resources. Mobutu was forced out of power after demonstrating only a minimum of interest to resolve the Congolese political crisis. President Kabila seemed in no hurry to address people's grievances while alienating the foreign military elements that had assisted him into power. When armed rebel groups rose against Kabila, some of these foes received assistance from Kabila's former external supporters such as Uganda and Rwanda. Kabila had to guard the interests of his new supporters such as Zimbabwe, Angola, and Namibia whose presence turned out to be inimical to conflict resolution. The external supporters came as Kabila's guests whose interests however exacted a heavy price on peace prospects in the DRC, a situation much linked to the level of commitment to peace.

To a large degree Kabila's unwillingness to implement the Lusaka Agreement concluded with the internal and international players can be explained by competing demands among his enemies and allies. At his death in January, 2003, President Laurent Kabila had not demonstrated any strong desire and will for lasting peace or acquiescence to democracy. The president and the disillusioned Congolese operated at loggerheads, with Kabila who explained his dictatorial approaches to government as a political expediency for a situation still in a destabilised and fluid state. In Mozambique President Chissano, determined to achieve peace with only one major rebel group, RENAMO, was personally interested in peace notwithstanding the ideological recasting it demanded. The extent of foreign military intervention in Mozambique was more organised and better defined than in the DRC. Laurent Kabila's successor, the son Joseph, came to consider peace a priority within the framework of the Lusaka Agreement which had been largely disregarded by his father. 
Unlike Chissano in Mozambique Laurent Kabila avoided humbling himself to accept or compromise on his opponents' demands. Joseph Kabila's resolve for peace was demonstrated in the signing of the Pretoria Agreement (2003) and, prior to this action, the expulsion of foreign military forces. In peace negotiation and agreement local ownership of the results is critical to the successful implementation of the effort, and at the centre of the achievement of the Inter Congolese Dialogue remained the involvement of all internal parties that signed the Pretoria Agreement 2003. A military victory for the Kabila government had proved elusive, and the only realistic option seemed to be negotiations. The implementation of any agreement starts with teething problems, and the tragedy of HemaLendu ethnic fighting in Bunia in the northeast of DRC in 2003 was to be seen in this light. Kabila, succeeding rapidly in gaining popular and international confidence, had exhibited the necessary political will in defence of the Pretoria Agreement and the choice of the United Nations as the legitimate body to monitor and protect the peace accord which was successfully brokered largely by SADC countries led by South Africa.

While for a long time natural resources such as diamonds and indeed timber blurred the focus of genuine peace negotiation in the DRC, Mozambique on the contrary could not claim equal endowment with such attractions. However, realism led Joseph Kabila in a spirit of tolerance, to resurrect dialogue around the Lusaka Peace Accords, reinstated the United Nations facilitator, Sir Ketumile Masire, unbanned political parties for inclusiveness in the ensuing national dialogue, moves which enchanted even Uganda and Rwanda some of whose troops were pulled back to give peace a chance as long as pro-government Zimbabwe and Angola reciprocated.

Kabila operated in this process against the background of self-financing war makers who had benefited from Congolese minerals and other natural resources to undermine international pressure aimed at stopping the fighting. In any case the enormous profiteering from minerals reduced the attraction among the beneficiaries of a sustainable peace agreement that would alter the set up of economic exploitation. The list of the profiteers and exploiters of the Congolese resources presented by the United Nations team to the Security Council in 2003 strongly supported the point. Where conflict revolves around resources, and power to control the allocation and access of the resources, the creation of a social or political identity that will service the power base in government and direct the economic infrastructure creates difficulties in implementing a peace accord. These interests applied to the DRC.

Negotiating and reaching a good peace accord creates an onerous task whose ultimate value lies in the successful implementability of the resultant agreement. Negotiations based on conciliatory concessions tend to lead to an agreement relatively easy to implement. Such accords reflect the existence of negotiating rules and principles which ensure clarity of communication that will avoid misunderstanding of ultimate goals. 


\section{Multilateral Involvement in Peacebuilding}

The character of peace negotiations and agreement in the DRC and Mozambique was marked by both bilateral and multilateral involvement, as observed. However it is at the peace management stage when the multilateral organizations such as the United Nations featured more prominently. In the case of the DRC the pivotal role of the Southern African Development Community (SADC) in the negotiations recognized the recent track record of the UN in the management of peace agreements. In Mozambique the agreement between the government and RENAMO brokered by the Community of San Egidio benefited from the United Nations involvement in the implementation, considering the UN financial backing of the activities of the Peace Agreement which included peacekeeping, disarmament, demobilization, resettlement and integration.

The Mozambique peace process left some useful lessons of potential use in other situations of conflict. Experience in Mozambique revealed that:

a) attention must be centred on the core issues of the conflict. Mediators gained from local Mozambicans enormous understanding of the various details that assisted in devising strategies of resolution in an environment of local receptivity.

b) the peace framework must be designed to effectively operate within the defined target situation for credibility. Local mediators must enjoy acceptability by both parties based on competence, "creativity, patience and determination". 25

c) the character of the peace process should always shift from a platform of confrontation to one of mutual respect, confidence and trust. This forms the initial stage as an important prelude to the substantive peace agenda. In the case of Mozambique other African countries such as Zimbabwe, Botswana, South Africa, Kenya and Malawi played their part in the preparatory mediation to build the stage for the parties to engage in constructive dialogue.

d) the signing of the peace agreement introduces a delicate period of final dialogue and reconciliation to build bridges for national unity. The success of the difficult challenge of effective peace implementation depends not only on the local ownership of the accord but also international goodwill and readiness to provide the requisite financial support for reconstruction. Donors follow a peace agreement; their role in the process of peacemaking can determine the success or failure of peace and reconciliation in a given country. It must be noted that post-conflict arrangements designed to sustain peace building can serve as the flipside of preventive diplomatic strategy to arrest recurrence of a conflict, hence its delicate nature. While peace-making may include the international community, this international involvement is more pronounced in the management of the implementation of a peace agreement. The signing of a peace accord calls for meticulous effort to continue dialogue that promotes its peaceful 
launching and reconciliation as the key to durable peace which must be nurtured by constant monitoring and verification.

Successful involvement by the international community and multilateral organizations in resolving violent conflicts has been associated with "ripeness" 26 of the situation. A proper perception of the stage of ripeness for intervention is key to the identification of the existing problems for suitable peace resolution strategies to be designed. Occasionally the United Nations has been blamed for wrong intervention leading to its ineffectiveness. Similarly the United States intervention in Somalia under President George Bush Sr. turned out to be ill timed. Misconceptions existed about the operation of the conflict and the correct mode of intervention which excluded a properly worked out mechanism for peace negotiations.

The role of the United Nations in conflicts has recently been presented as "principally to assist national Governments and their local counterparts in finding solutions to their problems by offering support for the development of national and regional capacities for early warning, conflict prevention and long-term peace-building". ${ }^{27}$ In the DRC the UN role in peace-building proved the most delicate and complicated because sporadic fighting continued even after the signing by all warring parties of the comprehensive Pretoria Agreement. However, total cessation of hostilities and confidence building takes time and occasional fighting cannot be ruled out in the process of peace-building. Such eruptions of violence can be handled by continued peace discussions and interpretation of the agreement to address the remaining unresolved issues that intervene against sustainable peace. This remnant situation of conflict often characterises a peace which has left out a belligerent side. As Kriesberg suggests, "an agreement that is violated is a source of mistrust and renewed struggle. A sound agreement is one that is self-enforcing giving both sides reason to comply with the agreement.",28

The most visible role of the UN in the DRC peace process had been through MONUC (United Nations Mission to the Congo) operating mainly as an observer mission, in accordance with its mandate. Since the coming of Joseph Kabila as President of the DRC and the revival of the Lusaka Agreement spurned earlier by his father, the United Nations interest extended from the mere purview of MONUC to diplomatic engagement including the appointment of a Special Representative of the Secretary-General (SRSG) to collaborate with regional and local players such as the government and other entities in an effort to lend meaning to real peace based on reconciliation and understanding.

The success in the performance of the United Nations in peacemaking depends on the cooperation of other international players. In the DRC the United Nations initially failed to

See Zartman, I. William, Ripeness: The Hurting Stalemate and Beyond, Idem pp. 225-244 (photocopy).

27

"Prevention of armed conflict: Report of the Secretary-General" p.7.

28

Kriesberg, Louis, Constructive Conflicts: From Escalation to Resolution, Oxford 2003, p. 295. 
enjoy full American support; instead the United States encouraged elder Kabila to distance himself from the international organization's investigations of massacres and human rights violations. The United States support for Laurent Kabila was based on a desire to continue the exploitation of natural resources, forestall Islamic fundamentalism in East Africa and a quest to dislodge French influence. Unlike the case in Mozambique where America had no special economic and geopolitical interests, the United Nations' close involvement leading to the signing of the General Agreement in Rome and in the post-conflict peace-building was not resented by the United States. Mozambique witnessed the operation of an integrated framework of peace-building, with the United Nations playing a leading and coordinating role.

The involvement of the United Nations in given conflict situations requires understanding of its mandate for proper appreciation of its role both during the conflict and the postconflict periods. The United Nations has used Chapter 7 of the UN Charter which supports military intervention, sparingly, preferring to operate in a country of conflict from a distance through actions such as sanctions. However, sanctions need to be carefully selected for effectiveness to achieve the intended outcomes. Although many players plundered the Congolese natural resources with impunity to enrich themselves, economic sanctions against these groups would have proved untenable.

In the DRC, considering the ineffectiveness of MONUC to put down the remnants of armed rebellion, the United Nations Security Council decision on armed intervention had to identify an international leader for such an undertaking, and France decided to lead an international military force in Bunia in north eastern Congo. But this type of leadership, similar to that of the British in Sierra Leone and of the United States proposed for Liberia, required sufficient resources as an imperative for effective implementation of what should always be an appropriate strategy which must embrace the post-intervention arrangements including humanitarian involvement. In the DRC the success or failure of United Nations ultimately depended on the level of material and political support from Member States.

In Mozambique, reconciliation, the pivot of any peace, was demonstrated as the only guarantee in the resolution of hostilities and needed to be reflected in both political and socio-economic structures. Only when the envisioned future relationships rest on reliable arrangements of peace can transformation take place to involve movement of the groups in conflict from crisis to the desired change into peace-building through integration.

Transformation in any conflict zones involves both mental and practical processes of the human experience in peace-building in an integrated manner. Strategies of this integration, as Lederach suggests, must include the design of social change in timeframes, proper understanding of the causes of the crisis to develop potent approaches and finally identification of a proper leadership with ability to relate to various levels of the population from the grassroots to the top in order to make any suggested political and social change effective through intentional intervention that will promote communication and understanding. This understanding "brings to the surface the relational fears, hopes and goals of the people 
involved in terms of affectivity and interdependence". 29 This approach starts from the substructural level for proper perspective to comprehensively address conflict transformations with creativity in identifying mechanisms for peaceful change. The goal is "the generation of continuous, dynamic, self-generating processes that maintain form over time and are able to adapt to environmental changes" ${ }^{, 30}$ at all levels of the society. This was the process needed in the DRC which required time for the UN participation to fully achieve the desired outcomes of peace.

\section{Conclusion}

The role of the United Nations in the Congo had for a long time been less defined on the peace building front than in Mozambique following peace agreements in the two countries. The resistance to peace among some of the rebel factions in the DRC complicated the UN intentions for sometime, forcing the international community into the decision for a multinational force ready for provoked military action. The UN can be credited for some useful contribution in the Congolese peace process initially marked by the peace observing presence. However the UN role is most visible in the post-conflict reconstruction phase when its developmental agencies define their planned operations to rebuild the plundered country. The local responses both at governmental and local levels to UN socio-economic initiatives constitute the key to the success of rebuilding a war-devastated country. The UN's part in the rebuilding of Mozambique has represented an inspiring model of success which has reasonably been repeated in the DRC with enormous investments from the generosity of the international community.

In the end dynamics and mechanism for resolution of conflicts in Africa vary between the colonial and post-colonial epochs. Many generalities and commonalities may exist in colonial conflicts but disparities and uniqueness often feature in post-colonial violent hostilities which take the form of civil wars with the intensity depending on the numbers and aspirations of interest groups. These variations will determine the success and sustainability of peace interventions and peace agreements. The situation is complicated by external interventionists and their interest, making peace difficult in a country such as the DRC where economic prospecting formed a preponderant attraction for foreign forces than peace. The absence in Mozambique of natural resources such as minerals limited foreign interests mainly to geopolitical considerations whose magnitude had scaled down with the demise of communism. Peace-building and reconstruction thus proved easier in Mozambique than in the Democratic Republic of Congo. With the formation of an inclusive government of national unity prospects of genuine and sustainable peace in the DRC became a real possibility, on the road to a democratic constitution, elections and government. 